\title{
FORMACIÓN DE EDUCADORES \\ DE PÁRVULOS COMO SERVICIO A LA SOCIEDAD'
}

\section{EARLY CHILDHOOD EDUCATOR}

TRAINING AS A SERVICE TO SOCIETY²

\section{FORMAÇÃO DE EDUCADORES DE CRIANÇAS COMO UM SERVIÇO À SOCIEDADE}

\author{
María Eliana Arias Meriño \\ Universidad Bernardo O'HIgGins, Chile
}

RESUMEN: El presente trabajo representa una pequeña parte de una investigación realizada en la Universidad Bernardo O 'Higgins (UBO) de Chile, que aspira a ser reconocida como un referente nacional en la formación de graduados y profesionales de excelencia. El objetivo general que se persigue es ofrecer a la sociedad un servicio a través de la evaluación del Programa de la titulación de Pedagogía en Educación Parvularia ${ }^{3}$ con mención en $\mathrm{NB}_{1}^{4}$ de dicha Universidad. Se trata de responder al problema: ¿Existe coherencia entre en el Programa de Formación de Educadores de Párvulos (FEP) y el Proyecto educativo presentado por la UBO?

Después de desarrollar una aproximación conceptual a la investigación educativa y a los modelos de evaluación de programas educacionales, se opta por utilizar el modelo analítico de Stufflebeam (1987) orientado al Contexto- Insumo- Proceso- Producto (CIPP), siguiendo la estructura indicada por Pérez Juste (1995 y 2000), en tres momentos:

1) El Programa en sí mismo: calidad intrínseca del Programa, adecuación al contexto, adecuación de la situación de salida;

2) El Programa en su desarrollo: ejecución del Programa y marco de desarrollo del Programa;

3) El Programa en sus resultados: medida y logros, valoración y continuidad.

Cada uno de los momentos se ha organizado en torno a dimensiones y sus respectivos indicadores, con los cuales se han elaborado los instrumentos que han permitido medir las diferentes etapas conducentes a la evaluación final del Programa. 
Para la elección de la muestra se identificaron las poblaciones entre los años 2009 a 2011. Para el estudio de los datos se consideraron los diferentes niveles de la formación, las fuentes documentales del Programa y las fuentes empíricas representadas por los alumnos y profesores.

Entre los instrumentos utilizados destacan la matriz de referentes del Programa de los educadores de párvulos y del análisis documental sobre el contenido del Programa y sus bases psico-científicas; pautas de entrevista con el jefe de Carrera y profesorado; encuestas de opinión al alumnado, directivos y profesores.

Se han utilizado las siguientes fuentes: Registros oficiales y documentales, profesorado, alumnado y Jefe de Carrera de las promociones mencionadas del Programa de Formación de Educadores de Párvulos con mención en $\mathrm{NB}$, de la misma Universidad.

Entre los resultados obtenidos del estudio pueden mencionarse los siguientes: la presencia de las orientaciones, políticas y requerimientos del modelo educacional de la institución UBO; la inexistencia de relación entre las propuestas indicadas en los documentos oficiales de la Carrera con la gestión curricular en sus aspectos de liderazgo y ejecución de acciones, como también en los elementos de coherencia, interacción y secuencia de éstas para asegurar la concreción de lo planteado; no hay claridad-desde la perspectiva de los estudiantes y profesores- en los niveles de logro, pues no existen referentes anteriores concretos y los propios del desarrollo de la Carrera con criterios claros y comunes; se detecta rigidez de las programaciones y planificaciones, la falta de comunicación real entre los actores, la falta de metodologías variadas, la poca comunicación con los profesores y Jefe de Carrera y la falta de liderazgo del jefe de Carrera.

Con la presente investigación la UBO ha prestado un servicio de gran interés para la sociedad chilena y el profesorado universitario.

PALABRAS CLAVE: Educación de párvulos; formación de profesores; evaluación de programas; programas de enseñanza; investigación evaluativa; análisis documental; técnica de investigación.

ABSTRACT: This paper presents a small portion of a research project conducted at Chile's Bernardo O'Higgins University (UBO), which aspires to recognition as a national pacesetter in the education of outstanding graduates and professionals. The general objective of the research is to do society a service by assessing the UBO's early childhood education degree programme (major in first-year primary school teaching) and to verify the consistency between what the system requires for the development of teachers at that level and what actually gets implemented. This is a response to the problem: Is there consistency in the Teacher Training Program for Toddler and educational Project presented by the UBO?

A conceptual approach is taken to education research and the models for evaluating educational programmes. Stufflebeam's CIPP (Context-Input-Process-Product) model (1987) is chosen, and the structure indicated by Pérez Juste (1995 and 2000) is followed at three points:

1) the programme in itself: the programme's intrinsic quality, its context fit and its output situation fit;

2) the programme in its implementation: programme execution and framework of programme implementation;

3) the programme in its results: measurement and achievements, assessment and continuity.

Each of the points is organized in terms of dimensions and their respective indicators. Instruments are created for measuring the different stages leading to the programme's final evaluation.

To choose the sample, the populations between 2009 and 2011 are identified. To study the data, the different levels of teacher education are regarded, considering the programme's documentary source material and the empirical source material represented by students and faculty. 
Leading among the instruments used are a matrix of benchmarks for the early childhood educator programme and documentary analysis of the programme's content and psycho-scientific foundations; guidelines for interviewing the department director and faculty; and opinion surveys administered to students, managers and faculty.

The following sources are used: official records, documentary records, faculty, students and the department director promotions mentioned Training Program Toddler Educator with a major in NB1, of the same university.

Between the results obtained of the study they can be mentioned the following: orientations, policies and requirements are present in the UBO's educational model; no relationship exists between the goals stated in the official degree documents and curricular management in terms of leadership and action execution, or in the elements of consistency, interaction and action sequencing to ensure goal attainment; there is no clarity (from the standpoint of students and faculty) in levels of achievement, because there are no specific pre-established benchmarks or milestones for achievement during the programme with clear, shared criteria; the evaluation detected rigidity in programming and planning, lack of real communication among stakeholders, lack of varied methodologies, poor communication with faculty and the department head and lack of leadership on the part of the department head.

With this research the UBO has rendered a service of great interest to Chilean society and university faculty.

KEYWORDS: Early childhood education, teacher education; program evaluation; teaching programme; evaluative research; documentary analysis; research technique.

RESUMO: O presente estudo representa uma pequena parte de uma pesquisa levado a cabo na Universidade Bernardo O 'Higgins (UBO), do Chile, que aspira a ser reconhecido como um líder nacional na formação de diplomados e profissionais de excelência. O objectivo geral é oferecer um serviço à sociedade, por da avaliação do programa de grau do ensino na educação de infância com especialização na Universidade NBi. Endereçamento para o problema: há coerência entre os educadores de formação programa de crianças (FEP) e o projeto educativo apresentado pelo UBO?

Depois de desembrulhar uma abordagem conceitual para a pesquisa educacional e modelos de avaliação de programas educacionais, opta por usar o modelo analítico de Stufflebeam (1987) orientado para o processo de contexto - entrada - produto (CIPP), seguindo a estrutura indicada por Pérez Juste (1995 e 2000), em três momentos:

1) o programa em si: qualidade intrínseca do programa, adaptação ao contexto, adequação da situação de partida;

2) o programa em seu desenvolvimento: implementação do programa e o quadro de desenvolvimento do programa;

3) o programa em seus resultados: medida e realizações, avaliação e continuidade.

Cada um dos momentos foi organizado em torno de dimensões e seus respectivos indicadores, que foram elaborados instrumentos que permitiram medir as diferentes fases levando a avaliação final do Programa.

Para a escolha das populações exemplo identificado entre os anos 2009 a 2011. Diferentes níveis de formação, documentários fontes do programa e as fontes empíricas representadas por professores e alunos foram considerados para o estudo dos dados.

Os instrumentos utilizados incluem a matriz de referências do programa para educadores de infância e a análise documental sobre o conteúdo do programa e suas bases psico-científico; padrões de entrevista com o chefe da carreira e docentes; pesquisas de estudantes, executivos e professores. 
Foram usadas as seguintes fontes: registros formais e documentais, professores, estudantes e cabeça de carreira de acima os professores de berçário formação programa promoções com menção na $\mathrm{NB}$, pela mesma universidade.

Os resultados do estudo incluem o seguinte: a presença de diretrizes, políticas e requisitos do modelo educacional da instituição UBO; a falta de relação entre as propostas referidas nos documentos oficiais da raça com a gestão do currículo nos aspectos de liderança e execução das acções, bem como os elementos de coerência, a interação e a sequência destes para garantir a realização das questões levantadas; não há nenhuma clareza - na perspectiva de alunos e professores - a níveis de realização, como há nenhum concreto de referências anteriores e as relacionadas com o desenvolvimento da raça, com critérios claros e comuns; rigidez da programação e planejamento é detectado, a falta de comunicação real entre os atores, a falta de metodologias variadas, pouca comunicação com professores e carreira Manager e falta de liderança do chefe de Carrera.

Con esta pesquisa UBO serviu um grande interesse por conferencistas chileno de sociedade e Universidade

PALAVRAS-CHAVE: educação de infância; professor de formação; avaliação de programas; programas de educação; Investigação avaliativa; análise documental; técnica de pesquisa. 


\section{Introducción}

Respondiendo al título del presente trabajo, abordaremos brevemente algunos estudios relacionados, tanto con la formación de los profesores ${ }^{5}$, como los modelos principales utilizados para la evaluación de Programas.

En el contexto mundial y particularmente en Chile, se ha hecho necesario tener una base educativa preescolar sustentada en valores culturales propios, tema de permanente debate tanto en el ámbito social, como en el propio de la reflexión educacional. Este debate se genera por la globalización, que cada vez exige formas diferentes de convivencia social y preparación de los profesionales.

\section{Estudios relacionados con la temática del trabajo}

Seguidamente mencionamos algunos estudios relacionados con la formación del profesorado.

\subsection{Formación del profesorado}

En la sociedad actual los cambios producidos en todos los ámbitos, laborales, tecnológicos, formas de vida, uso del tiempo libre, etc., repercuten de forma inevitable en las instituciones escolares $y$, en ellas, en su profesorado, en la formación inicial del futuro docente. Actualmente se propone una formación intercultural en la formación del profesorado, con un cambio curricular (Aguado, Gil \& Mata, 2008).

En otro estudio llevado a cabo por Garrido Arroyo (1999, 782-783) se llega a algunas conclusiones como las siguientes:

- Los cambios producidos en la sociedad actual tienen una incidencia directa en las instituciones educativas de cualquier nivel $y$, por tanto, en la función de los docentes de estas instituciones.

- Los docentes necesitan adaptarse a las nuevas situaciones provocadas por los cambios sociales (...)

- Necesidad de una formación inicial en la que el profesorado universitario también asuma nuevas funciones para amoldarse a los cambios (...)

\section{Introduction}

As may be gathered from the title, this paper takes a brief look at a number of studies related with teacher training and the main models used in programme evaluation.

In the worldwide context, and particularly in Chile, it has become necessary to build a foundation that rests on local cultural values for preschool education. This issue is the subject of constant debate in society at large and among thinkers devoted to education. The debate is fanned by globalization, which is requiring more and more different kinds of peaceful co-existence in society and preparation for educators.

\section{Studies Related with the Topic of the Paper}

Let us review some of the studies related with teacher training.

\subsection{Teacher Training}

In today's society, the changes happening in every sphere -work, technology, lifestyle, leisure- inevitably have an impact on schools, the teachers in them and the pre-service training of future educators. The proposal now in vogue advocates intercultural training in teacher education, with a change of curriculum (Aguado, Gil \& Mata, 2008).

Another study conducted by Garrido Arroyo (1999, 782-783) reaches conclusions such as these:

- The changes that happen in today's society have a direct effect on educational institutions of all levels and therefore on the function of the educators at those institutions.

- Educators need to adapt to the new situations caused by social changes (...).

- There is a need for the university faculty involved in pre-service teacher training to take on new functions in order to adjust to the changes (...).

The research work done by Jiménez \& Navaridas (2012) draws the profile of an exce- 
Es de destacar la investigación llevada a cabo por Jiménez \& Navaridas (2012), en la que llegan a identificar el perfil de un maestro excelente: cualidades, capacidades, sensibilidad, etc.

Maciel de Oliveira (2003) considera que en Estados Unidos se ha producido un aumento de investigaciones acerca de la formación del profesorado, sin embargo, no ocurre así en el contexto latinoamericano, pues, recogiendo la frase de Cornejo $(1999)^{6}$ la problemática del profesor debutante en cuanto objeto de investigación es "cuasi-inexistente".

Por nuestra parte, igualmente consideramos que la literatura disponible en Chile sobre el desarrollo de la formación de educadoras de párvulos, es muy escasa o inexistente. Más aún, en los textos expresivos de las políticas educativas de estos años como el Informe Brunner (1995) o el Informe de la OECD (2004), por ejemplo, si bien la formación de los profesores aparece como un tema crítico, no hay ninguna mención especial a la formación de los educadores de párvulos.

Finalmente, mencionaremos el trabajo publicado por la UNESCO (Murillo, 2006). En él se presentan siete modelos innovadores que consideran las tendencias del futuro; entre ellos destaca el desarrollo de competencias como elemento para superar los contenidos y la interrelación teoría-práctica en la formación inicial de los docentes.

\subsection{Evaluación de Programas}

El segundo ámbito de este trabajo es el relacionado con la evaluación de programas. Teniendo en cuenta algunas de las definiciones aportadas por Coll (1978 \& 2008), Fernández Sierra y Santos (1992), Beltrán y San Martín (1993) ${ }^{7}$, Himmel y otros (1999) nos hemos detenido en la normativa de la educación chilena -Decreto de Evaluación no 112, 1999), así como en la perspectiva de la investigación evaluativa presentada por Pérez Juste $(1995,2000)$ y los fines que persigue la misma analizados por Pérez Serrano (2001).

Por otra parte, en nuestro trabajo tenemos presente los diversos los modelos de evaluación de Programas que presenta Horrillo (2005), tales como:
Ilent schoolteacher: qualities, abilities, sensitivity, etc.

Maciel de Oliveira (2003) considers that the United States has seen an upsurge in research into teacher training. The same cannot, however, be said of the Latin-American context; to borrow a turn of phrase from Cornejo (1999), 8 the problem of the newfledged teacher as an object of research is "quasi-non-existent".

We too consider that the literature available in Chile on the development of early childhood educator training is very sketchy or non-existent. And we would go farther. Texts reviewing the educational policies of recent years, such as the Brunner Report (1995) and the OECD Report (2004), do address teacher training as a critical issue, but they make no particular mention of training for early childhood educators.

Lastly, the paper published by UNESCO (MuriIlo, 2006) presents seven innovative models that consider the tendencies of the future; foremost among them is the development of competences as a means of mastering content and the interrelation between theory and practice in pre-service educator training.

\subsection{Programme Evaluation}

The second topic addressed in this paper is programme evaluation. Taking account of some of the definitions furnished by Coll (1978 \& 2008), Fernández Sierra and Santos (1992), Beltrán and San Martín (1993) 9 and Himmel et al. (1999), we focus on Chilean education legislation (Evaluation Decree No. $112,1999)$, the perspective of the evaluation research presented by Pérez Juste (1995 and 2000) and the goals sought, as analyzed by Pérez Serrano (2001).

The various programme evaluation models presented by Horrillo (2005) have been borne in mind as well, including:

a) Ralph Tyler's classic model (1949 and 1950), goal attainment (verification or congruence), goal-oriented evaluation. 
a) Modelo clásico de Ralph Tyler (1949 y 1950) logro de metas (verificación o congruencia), evaluación orientada al logro de los objetivos.

b) Modelo de Robert Stake (1967 y 1975), evaluación respondente o centrada en el cliente, evaluación sensitiva o concertada ("responsive evaluation").

c) Modelo de Daniel Stufflebeam (1987), evaluación orientada a la toma de decisiones, modelo de contexto, insumo, proceso, producto -CIPP-.

d) Modelo de Michael Scriven (1997), la evaluación como la ciencia del valor, sin objetivos prefijados, orientada a las necesidades del consumidor

e) Modelo de evaluación iluminativa de Parlett y David Hamilton (1972 y 1977) orientado inicialmente a evaluar cursos en la Educación Superior en el área de la psicología y educación.

f) Modelo de evaluación de Elliot Eisner (1974, 1994), basado en la crítica artística.

g) Modelo de Egon Guba y Lincoln (1989), la evaluación naturalista.

h) Modelo de Peter H. Rossi (1971), la evaluación comprensiva.

i) Modelo de R. Pérez Juste (2000), orientación para la práctica educativa.

A continuación, presentamos unas ideas generales de la educación en Chile.

\subsection{Situación de la educación chilena}

En el ámbito educacional chileno se ha planteado, a partir de 1990, una trasformación significativa del sistema educativo, que asume dos lineamientos político-estratégicos: primero, el mejoramiento general de los resultados educativos de la población y, segundo, la actualización de sus competencias para su mejor incorporación al mercado del trabajo.

El proceso de formación del educador de párvulos es de real importancia, dado su rol de orientador y mediador del proceso de aprendizaje del primer nivel educativo del sistema; la responsabilidad de esta formación está inserta b) Robert Stake's model (1967 and 1975), responsive or client-centred evaluation, sensitive or concerted evaluation.

c) Daniel Stufflebeam's model (1987) evaluation oriented toward decision making, context, input, process and product (CIPP) model.

d) Michael Scriven's model (1997), evaluation as the science of worth, without pre-set objectives, is oriented to the consumer's needs.

e) Parlett and David Hamilton's model of illuminative evaluation (1972 and 1977), oriented initially toward the evaluation of higher education in the area of psychology and education.

f) Elliot Eisner's evaluation model $(1974,1994)$ is based on artistic criticism.

g) Egon Guba \& Lincoln's model (1989), naturalistic evaluation.

h) Peter H. Rossi's model (1971), comprehensive evaluation.

i) R. Pérez Juste's model (2000), orientation for education practice.

Let us now explore an overview of education in Chile.

\subsection{The Situation of Chilean Education}

Since 1990 the Chilean educational system has been undergoing a significant transformation. The change takes the form of two political and strategic lines: first, a general improvement of the population's educational performance and, second, an effort to update the population's competences for smoother incorporation into the job market.

The process of training early childhood educators is very important, given the role such educators play as guides and mediators of the learning process at the education system's very first level. The responsibility for early childhood educator 
en la Educación Superior, regulada por el Ministerio de Educación -Mineduc- mediante diferentes disposiciones, entre las cuales se encuentran los Criterios de Evaluación de Carreras de Educación.

Entre los organismos educacionales que han asumido el desafío de la formación de Educadores de Párvulos se encuentran las universidades estatales y autónomas. El modelo educacional de la Universidad que nos ocupa se desprende de los siguientes componentes institucionales: Plan Estratégico - Misión- Visión Proyecto Educativo y Principios, Valores y Propósitos institucionales. Respecto del Plan Estratégico, a partir de 2010, se ha desarrollado un completo proceso de apreciación de antecedentes y de actualización de los datos que configura la realidad actual, para llegar a establecer un plan estratégico que guiará las acciones previstas para esta nueva etapa de la vida institucional.

\section{Fases de la evaluación de Programas}

Siguiendo a los autores mencionados anteriormente, presentamos sintéticamente los criterios de evaluación que se incluyen en nuestro estudio para ser utilizados en cada uno de los momentos y dimensiones de su aplicación.

\subsection{Momento inicial: el Programa en sí mismo}

En cada uno de los momentos de la evaluación, indicamos las dimensiones, el objetivo y los indicadores de la misma. A continuación presentamos la Tabla 1 correspondiente al Momento 1 (M.1). training has been assigned to higher education, governed by the Ministry of Education (Mineduc) through rules and regulations that include the Education Degree Evaluation Criteria.

State-run and autonomous universities numbered among the educational institutions that have taken up the challenge of training early childhood educators. The educational model of a particular university may be gathered from the following institutional components: strategic plan; mission; vision; educational project and principles; institutional goals and values. We will begin with the strategic plan. In 2010 a process (now complete) was put in train to weigh up the past record and update the data that reveal the real current situation, in order to map out a strategic plan to steer the actions planned for this new stage of institutional life.

\section{Phases of Programme Evaluation}

Following the authors mentioned above, we present a succinct review of the evaluation criteria included in our study for using it at each point in evaluation and the dimensions of each criterion's application.

\subsection{Point One: The Programme in Itself}

At each point in evaluation, the dimensions, the objective and the evaluation indicators are given. Table 1 (below) refers to the initial point, Point 1 (P.1). 
Tabla 1. Dimensiones, objetos, indicadores (M.1)

\begin{tabular}{|c|c|c|}
\hline Dimensiones & Objeto & Indicadores \\
\hline \multirow{3}{*}{$\begin{array}{l}\text { Calidad intrínseca del } \\
\text { Programa }\end{array}$} & Contenido del Programa & $\begin{array}{l}\text { Coherencia entre contenidos y las bases sociopsico- } \\
\text { científicas del Programa }\end{array}$ \\
\hline & Calidad técnica & Adecuación de los alumnos \\
\hline & Evaluabilidad & Relevancia de la información disponible \\
\hline \multirow{3}{*}{ Adecuación al contexto } & & Coherencia interna entre los componentes \\
\hline & Respuestas a necesidades / creencias & Congruencia entre Programa y necesidades \\
\hline & Priorización & Establecimiento de prioridades conforme el contexto \\
\hline \multirow{5}{*}{$\begin{array}{l}\text { Adecuación a la situación } \\
\text { de partida }\end{array}$} & \multirow{5}{*}{ Viabilidad } & Realismo en las metas \\
\hline & & Suficiencia de apoyos logrados \\
\hline & & Capacitación del profesorado \\
\hline & & Disponibilidad de los medios necesarios \\
\hline & & Demanda de los interesados \\
\hline
\end{tabular}

Table 1. Dimensions, Objects, Indicators (P.1)

\begin{tabular}{|c|c|c|}
\hline Dimensions & Object & Indicators \\
\hline \multirow{3}{*}{$\begin{array}{l}\text { Intrinsic quality of the } \\
\text { programme }\end{array}$} & Programme contents & $\begin{array}{l}\text { Consistency between the programme's contents and } \\
\text { its socio-psycho-scientific foundations }\end{array}$ \\
\hline & Technical quality & Student fitness \\
\hline & Evaluability & Relevance of the available information \\
\hline \multirow{3}{*}{ Fitness for the context } & & Internal consistency among components \\
\hline & & Congruence between programme and needs \\
\hline & Prioritization & Setting of priorities according to the context \\
\hline \multirow{5}{*}{$\begin{array}{l}\text { Fitness for the situation at } \\
\text { the outset }\end{array}$} & \multirow{5}{*}{ Viability } & Realism in goals \\
\hline & & Sufficiency of support actually achieved \\
\hline & & Teacher training \\
\hline & & Availability of the necessary resources \\
\hline & & Stakeholder demand \\
\hline
\end{tabular}




\subsection{Segundo momento: el Programa en su desarrollo}

Seguidamente presentamos en la Tabla 2 las dimensiones, objeto e indicadores del Momento 2 (M.2).

\subsection{Point Two: The Programme in Its Implementation}

Table 2 deals with the dimensions, object and indicators of Point 2 (P.2).

Tabla 2. Dimensiones, objeto, indicadores (M.2)

\begin{tabular}{|c|c|c|}
\hline Dimensiones & Objeto & Indicadores \\
\hline \multirow{9}{*}{ Ejecución } & Metodología & Adecuación para el desarrollo de los objetivos del Programa \\
\hline & Actividades & Interés de los alumnos por las actividades \\
\hline & Secuencias & Secuencia de las actividades programadas \\
\hline & Tiempo & Temporalización prevista \\
\hline & Flexibilidad & Rigidez/ flexibilización en la aplicación del Programa \\
\hline & \multirow{4}{*}{$\begin{array}{l}\text { El profesor en su actividad } \\
\text { docente }\end{array}$} & Respecto de la planificación \\
\hline & & En la revisión de los conocimientos del alumno \\
\hline & & En la presentación de los nuevos contenidos \\
\hline & & En la evaluación de los alumnos \\
\hline \multirow{4}{*}{ Marco } & \multirow{2}{*}{ Clima } & Entre el personal \\
\hline & & Relaciones con el alumnado \\
\hline & \multirow{2}{*}{ Coherencia } & Relación entre objetivos del Programa con proyecto educativo \\
\hline & & Confianza en el éxito por parte de alumnos y profesores \\
\hline
\end{tabular}

Table 2. Dimensions, Object, Indicators (P.2)

\begin{tabular}{|c|c|c|}
\hline Dimensions & Object & Indicators \\
\hline \multirow{9}{*}{ Execution } & Methodology & Adjustment for the implementation of the programme's objectives \\
\hline & Activities & Student interest in the activities \\
\hline & Sequence & Sequence of programmed activities \\
\hline & Time & Anticipated timing \\
\hline & Flexibility & Rigidity/flexibility in the application of the programme \\
\hline & \multirow{4}{*}{$\begin{array}{l}\text { The teacher in his teaching } \\
\text { activity }\end{array}$} & Respect for the plan \\
\hline & & In reviewing the student's knowledge \\
\hline & & In the presentation of new contents \\
\hline & & In the evaluation of students \\
\hline \multirow{4}{*}{ Framework } & \multirow{2}{*}{ Climate } & Among staff \\
\hline & & Relations with the student body \\
\hline & \multirow{2}{*}{ Consistency } & Relationship between programme objectives and the educational project \\
\hline & & Confidence in success on the part of students and teachers \\
\hline
\end{tabular}


De forma similar presentamos, a continuación, en la Tabla 3, las dimensiones, objeto e indicadores del Momento 3 (M.3).
Similarly, Table 3 gives the dimensions, object and indicators of the final point, Point 3 (P.3).

Tabla 3. Dimensiones, objeto, indicadores (M.3)

\begin{tabular}{|c|c|c|}
\hline Dimensiones & Objeto & Indicadores \\
\hline \multirow{4}{*}{ Medida y logros } & \multirow{4}{*}{ Constatación contraste } & Aseguramiento de la calidad técnica de las pruebas \\
\hline & & Planificación de pruebas \\
\hline & & Técnicas variadas de recogida de datos \\
\hline & & Criterios de calificación y niveles de logro \\
\hline \multirow{4}{*}{ Valoración } & Criterios referencias & Niveles conseguidos con el Programa \\
\hline & \multirow{3}{*}{$\begin{array}{l}\text { Decisiones. } \\
\text { Incorporación de las mejoras } \\
\text { Plan de seguimiento }\end{array}$} & Implicación de los responsables \\
\hline & & Existencia de un sistema de control interno \\
\hline & & Elaboración de un plan de seguimiento \\
\hline
\end{tabular}

Table 3. Dimensions, Object, Indicators (P.3)

\begin{tabular}{|c|c|c|}
\hline Dimensions & Object & Indicators \\
\hline \multirow{4}{*}{$\begin{array}{l}\text { Measurement and } \\
\text { achievements }\end{array}$} & \multirow{4}{*}{$\begin{array}{l}\text { Verification } \\
\text { Contrast }\end{array}$} & Assurance of the technical quality of tests \\
\hline & & Test planning \\
\hline & & Varied data collection techniques \\
\hline & & Grading criteria and achievement levels \\
\hline \multirow{4}{*}{ Assessment } & Criteria Benchmarks & Achievement levels attained with the programme \\
\hline & \multirow{3}{*}{$\begin{array}{l}\text { Decisions } \\
\text { Incorporation of improvements } \\
\text { Follow-up plan }\end{array}$} & Involvement by the people responsible \\
\hline & & Existence of a system of internal control \\
\hline & & Preparation of a follow-up plan \\
\hline
\end{tabular}

\section{Problema y objetivos de la investigación}

Partimos de la problemática planteada en esta investigación, como es: conocer la coherencia que presenta el Programa de la Carrera de Formación de la Educadora de Párvulos (en adelante FEP) con mención en $\mathrm{NB} 1$-en su estructura, desarrollo y logros- con el proyecto presentado por la UBO en el período 2009-2012.

En este sentido se pueden formular los siguientes objetivos específicos:

1. Detectar fortalezas y debilidades de la estructura del Programa de FEP con mención

\section{Research Problem and Objectives}

We begin with the problem posed in this research: to ascertain the consistency of the early childhood educator training (henceforth, "ECET") degree programme for majors in first-year primary school teaching with the project presented by Bernardo O'Higgins University for the 2009-2012 period. Consistency will be evaluated in terms of structure, implementation and achievements. In this sense, the following specific objectives may be formulated:

1. To detect strengths and weaknesses in the structure of the ECET programme for majors in first- 
en $\mathrm{NB} 1$, con respecto al proyecto educativo presentado por la universidad.

2. Contrastar el nivel de desarrollo de las propuestas indicadas en los documentos oficiales de la Carrera de Pedagogía en Educación Parvularia (en adelante PEP) con mención en $\mathrm{NB} 1$ con la ejecución de los aspectos curriculares de formación y valórica.

3. Determinar los niveles de logro de las propuestas indicadas en los documentos oficiales de la Carrera de PEP con mención en NBi desde la perspectiva de los docentes y estudiantes.

\section{Metodología empleada}

Se trata de una metodología combinada, con paradigma cualitativo-cuantitativo, mediante la investigación evaluativa, entendida como "procesos sistemáticos de recogida y análisis de información fiable y válida para tomar decisiones sobre un programa educativo" (Pérez, 2001, 39). Para ello se han usado instrumentos que han permitido la descripción, recolección de datos, interpretación y contraste de la información, como son:

1. Matriz de referentes del programa de formación de la educadora de párvulos.

2. Matriz de análisis documental sobre contenido del programa y sus bases socio psicocientíficas.

3. Pauta de entrevista con jefe de Carrera.

4. Pauta de entrevista con profesores.

5. Encuesta de opinión a alumnos.

6. Encuesta de opinión a directivos docentes y/o profesores.

7. Pauta de entrevista con jefe de Carrera.

8. Pauta de entrevista con profesores.

9. Encuesta de opinión a alumnos.

10. Encuesta de opinión a directivos docentes y/o profesores.

A continuación exponemos la población y muestra del estudio.

\subsection{Población y muestra}

La población está representada, por un lado, por el Programa de FEP de la Universidad, por los registros documentales de la implementación del Programa de year primary school teaching, with respect to the educational project presented by the university.

2. To compare the level of implementation of the proposals stated in the official documents on the early childhood education (henceforth, "ECE") degree for majors in first-year primary school teaching with the execution of the curricular and value-related aspects of training.

3. To find the levels of achievement of the proposals stated in the official documents on the ECE degree for majors in first-year primary school teaching from the perspective of teachers and students.

\section{Methodology}

A compound methodology was used featuring a qualitative/quantitative paradigm and employing evaluative research, a term that is taken to mean "systematic processes of collecting and analyzing reliable, valid information for taking decisions about an educational programme" (Pérez, 2001, 39). For this purpose, instruments designed for description, data collection and the interpretation and contrast of information were used:

1. A matrix of benchmarks for the early childhood educator training programme.

2. A documentary analysis matrix focussing on the programme's contents and socio-psychoscientific foundations.

3. Department director interview guidelines.

4. Teacher interview guidelines.

5. A student opinion survey.

6. An opinion survey administered to the teaching members of the administration and/or faculty.

Let us now discuss the population and the study sample.

\subsection{Population and Sample}

The population is made up of, first, the university's ECET programme; second, the documentary records on the implementation of the ECET programme for majors in first-year primary school teaching for the graduating classes participating in 
FEP con mención en NBi para las promociones de estudio, por 24 profesores del Programa y por las 69 alumnas del Programa de la Universidad (véase Tabla 4). this study; third, 24 teachers of the programme and, fourth, the 69 students enrolled in the programme at the university (see Table 4).

Tabla 4. Identificación de la población, muestra y criterios de selección de la muestra

\begin{tabular}{ll}
\hline Población 1 & Programas de FEP de la Universidad Bernardo O 'Higgins. \\
\hline Muestra1 & $\begin{array}{l}\text { Registros oficiales del Programa.Se trata de una muestra aleatoria intencional, conside- } \\
\text { rando que se trabajó con los antecedentes del Programa de FEP en actual vigencia. }\end{array}$ \\
\hline
\end{tabular}

Unidad de análisis $1 \quad$ Documentos del Programa.

Población $2 \quad$ Registros documentales de la implementación del Programa.

Registros documentales de la implementación del Programa de FEP con mención en

Muestra $2 \quad \mathrm{NB}$, de las áreas y períodos de mayor relevancia.Se trata de una muestra no aleatoria intencional, pues la selección de los registros según área y período se realizará según criterios de relevancia de estos en el análisis del programa.

Unidad de análisis 2

Cada uno de los registros documentales de la implementación del Programa de FEP con mención en NBi, de las áreas y períodos de mayor relevancia.

\begin{tabular}{ll}
\hline Población 3 & 24 profesores del Programa. \\
\hline Muestra 3 & $\begin{array}{l}18 \text { profesores de las promociones estudiadas.Muestra no aleatoria intencional, según do- } \\
\text { tación de profesores en el semestre primavera del año } 2011 .\end{array}$ \\
\hline Unidad de análisis 3 & $\begin{array}{l}\text { Cada uno de los profesores de las promociones de estudio-según dotación de profeso- } \\
\text { res en el semestre primavera del año 2011. }\end{array}$ \\
\hline Población 4 & 69 alumnas del Programa de Formación de la Educadora de Párvulos con mención en \\
& $\mathrm{NB}$, de la UBO.Se trabajó con el universo. \\
\hline
\end{tabular}

Table 4. Identification of the Population, Sample and Sample Selection Criteria

\begin{tabular}{|c|c|}
\hline Population 1 & ECET programme at Bernardo O'Higgins University. \\
\hline Sample 1 & $\begin{array}{l}\text { Official programme records. This is an intentional random sample, considering that work } \\
\text { was done with the past record of the ECET programme currently being applied. }\end{array}$ \\
\hline Unit of Analysis 1 & Programme documents. \\
\hline Population 2 & Documentary records of the programme's implementation. \\
\hline Sample 2 & $\begin{array}{l}\text { Documentary records of the implementation of the ECET programme for majors in first- } \\
\text { year primary school teaching, in the most significant areas and periods. } \\
\text { This is an intentional non-random sample, because the selection of records by area and } \\
\text { period was conducted according to criteria measuring the records' relevance in terms of } \\
\text { programme analysis. }\end{array}$ \\
\hline Unit of Analysis 2 & $\begin{array}{l}\text { Each of the documentary records on the implementation of the ECET programme for ma- } \\
\text { jors in first-year primary school teaching, in the most significant areas and periods. }\end{array}$ \\
\hline Population 3 & 24 teachers of the programme. \\
\hline Sample 3 & $\begin{array}{l}18 \text { teachers from the graduating classes that participated in the study. Intentional non-ran- } \\
\text { dom sample, according to teacher allocation in the spring semester of } 2011 .\end{array}$ \\
\hline Unit of Analysis 3 & $\begin{array}{l}\text { Each of the teachers of the graduating classes that participated in the study, according to } \\
\text { teacher allocation in the spring semester of } 2011 .\end{array}$ \\
\hline Population 4 & $\begin{array}{l}69 \text { students enrolled in the early childhood educator training programme for majors in } \\
\text { first-year primary school teaching at UBO. The study worked with the universe. }\end{array}$ \\
\hline
\end{tabular}


Tabla 5. Variables e instrumentos

\begin{tabular}{|l|l|}
\hline Para la variable dependiente & Instrumento \\
\hline $\begin{array}{l}\text { Estructura del Programa de Formación de la Educadora de } \\
\text { Párvulos con mención en NBi, de la UBO. }\end{array}$ & $\begin{array}{l}\text { 1. Matriz de referentes del programa de formación de la } \\
\text { educadora de párvulos } \\
\text { 2. Matriz de análisis documental sobre contenido del pro- } \\
\text { grama y sus bases socio psicocientíficas. }\end{array}$ \\
\hline Para las variables independientes & Instrumento \\
\hline $\begin{array}{l}\text { Desarrollo del Programa de Formación de la Educadora } \\
\text { de Párvulos con mención en NBi de la UBO }\end{array}$ & $\begin{array}{l}\text { 3. Pauta de entrevista con jefe de Carrera. } \\
\text { 4. Pauta de entrevista con profesores. } \\
\text { 5. Encuesta de opinión a alumnos }\end{array}$ \\
\hline $\begin{array}{l}\text { Nivel de logro de los objetivos curriculares y de los valores opinión a directivos docentes y/o profesores. } \\
\text { planteados por la institución desde la perspectiva de los } \\
\text { actores del proceso de formación de la Carrera de Peda- } \\
\text { gogía en Educación Parvularia con mención en NBi, repre- } \\
\text { sentados por los docentes y estudiantes }\end{array}$ & $\begin{array}{l}\text { 7. Pauta de entrevista con jefe de Carrera. } \\
\text { 9. Pauta de entrevista con profesores. } \\
\text { 10. Encuesta de opinión a directivos docentes y/o } \\
\text { profesores. }\end{array}$ \\
\hline
\end{tabular}

Table 5. Variables and Instruments

\begin{tabular}{|l|l|}
\hline For the Dependent Variable & Instrument \\
\hline $\begin{array}{l}\text { Structure of the early childhood educator training programme } \\
\text { for majors in first-year primary school teaching at UBO. }\end{array}$ & $\begin{array}{l}\text { 1. Matrix of benchmarks for the early childhood educator } \\
\text { training programme. } \\
\text { 2. Documentary analysis matrix focussing on the program- } \\
\text { me's contents and socio-psycho-scientific foundations. }\end{array}$ \\
\hline $\begin{array}{l}\text { For the Independent Variables } \\
\text { Implementation of the early childhood educator training } \\
\text { programme for majors in first-year primary school teaching } \\
\text { at UBO }\end{array}$ & $\begin{array}{l}\text { Instrument } \\
\text { 4. Teacher interview guidelines. } \\
\text { 5. Student opinion survey } \\
\text { 6. Opinion survey administered to teaching members of the } \\
\text { administration and/or faculty }\end{array}$ \\
\hline $\begin{array}{l}\text { Level of achievement of the curricular objectives and va- } \\
\text { lues established by the university from the perspective of } \\
\text { the active participants in the education process, represen- } \\
\text { ted by the teachers and students involved in the early } \\
\text { childhood educator training programme for majors in first- } \\
\text { year primary school teaching }\end{array}$ & $\begin{array}{l}\text { 7. Department director interview guidelines } \\
\text { 8. Teacher interview guidelines } \\
\text { 9. Student opinion survey } \\
\text { 10. Opinion survey of teaching members of the administra- } \\
\text { tion and/or faculty }\end{array}$ \\
\hline
\end{tabular}

\subsection{Técnicas e instrumentos}

Las variables de la investigación, están representadas por:

- Variable dependiente: Estructura del Programa de FEP con mención en NB1, de la UBO.

- Variables independientes: Desarrollo del Programa de FEP con mención en $\mathrm{NB}$, de la UBO y Nivel de logro de los objetivos curriculares y de

\subsection{Techniques and Instruments}

The research variables are represented by the following:

- Dependent variable: Structure of the ECET programme for majors in first-year primary school teaching at UBO.

- Independent variables: Implementation of the ECET programme for majors in first-year primary 
los valores planteados por la institución desde la perspectiva de los actores del proceso de formación de la Carrera de PEP con mención en $\mathrm{NB}$, representados por los docentes y estudiantes.

Los datos fueron recogidos con los instrumentos mencionados anteriormente y que se indican a continuación, en correspondencia con la variable dependiente y las variables independientes (véase Tabla 5).

\section{Análisis e interpretación de los resultados}

Los resultados más relevantes alcanzados en el estudio, los presentamos a continuación, diferenciando los del Programa en sí mismo, del Programa en su desarrollo y del Programa en sus resultados.

\subsection{Resultados del Programa en sí mismo}

Al analizar el Programa en sí mismo, nos fijamos en las dimensiones referidas a la "calidad intrínseca del programa", "adecuación al contexto" y adecuación a la "situación de partida". Veamos brevemente cada una de ellas.

\subsubsection{Calidad intrínseca del Programa}

Respecto a la calidad/contenido del Programa, los resultados del análisis indican que los aspectos valóricos indicados en la Misión de la Universidad, tienen coherencia con los objetivos del Programa relativos al "saber", al "saber ser" y al "saber hacer". Por otra parte, se registra mayor cantidad de objetivos asociados a la coherencia con el ámbito "Valorar el sentido de libertad, el respeto por la dignidad de las personas y el reconocimiento del mérito", que están representados por 13 objetivos.

Considerando la distribución y coherencia de las asignaturas del Área de Formación, los datos recopilados indican que de las 56 asignaturas que forman parte del plan de estudios, están distribuidas en 14 asignaturas por año y 7 por semestre; que en total consideran 3784 horas de clases, de las cuales 20 asignaturas están orientadas al "Área de Formación Básica", del "saber", con 1260 horas; 08 asigna- school teaching at UBO and level of achievement of the curricular objectives and values established by the university from the perspective of the active participants in the education process, represented by the teachers and students involved in the early childhood educator training programme for majors in first-year primary school teaching.

The data were collected with the instruments mentioned above and listed below, in correspondence with the dependent variable and the independent variables (see Table 5).

\section{Analysis and Interpretation of Results}

The foremost results of the study are presented below. The results in terms of the programme in itself, the programme in its implementation and the programme in its results are reported separately.

\subsection{Results of the Programme in Itself}

When analyzing the programme in itself, we narrowed in on the dimensions referring to "intrinsic quality of the programme", "fitness for the context" and "fitness for the situation at the outset". Let us briefly look at each.

\subsubsection{Intrinsic Quality of the Programme}

With respect to the quality/content of the programme, the analytical results indicate that the value-related aspects stated in the university's mission statement are consistent with the programme's objectives concerning "knowing", "knowing to be" and "knowing to do". Furthermore, the number of objectives associated with consistency with the sphere of "Valuing the sense of freedom, respect for personal dignity and merit acknowledgement" is larger; this sphere is represented by 13 objectives.

Considering the distribution and consistency of the courses in the training area, the data indicate that the curriculum's 56 courses are distributed into 14 courses per year and seven per semester. Altogether, these 56 courses take 3,784 classroom hours: In the "Basic Training Area" (the area of "knowing"), there are 20 courses, 1,260 hours; in the "General Training Area" (the area of "being"), there are eight 
turas están orientadas al "Área de Formación General", del "ser", con 396 horas; 28 asignaturas están orientadas al "Área de Formación Especializada o Profesional", del "saber hacer", con 2.128 horas.

No nos detenemos en este trabajo en analizar la distribución y coherencia de asignaturas según el año de formación en coherencia con el perfil.

En síntesis, podemos decir que el desarrollo de las asignaturas se van desplazando en su desarroIlo, según nivel académico, desde el área de Formación Básica (del saber) al área de Formación Profesional o Especializada (del saber hacer), centrándose en el primero y segundo año, las asignaturas propias del área de Formación General (del ser), en coherencia con el perfil de la Carrera.

\subsubsection{Adecuación al contexto}

Esta dimensión contiene la información respecto de las respuestas a necesidades / carencias y al establecimiento de prioridades conforme al contexto.

En el contexto que estudiamos, no existe dentro de la política de la Escuela, el realizar nivelaciones de las conductas de entrada de las alumnas, salvo las que realiza de manera individual el profesor. Los Programas están planificados de acuerdo a las necesidades de formación que exige el sistema de educación, pues debe presentarse ante la autoridad del Mineduc las programaciones generales con las condiciones de desarrollo de la Carrera para su posterior acreditación, lo que autoriza su funcionamiento en el tiempo; este proceso es secuencial, por tanto cada cierto tiempo se deben presentar las planificaciones a nivel macro.

\subsubsection{Adecuación a la situación de partida}

Este aspecto está referido a la viabilidad de ejecución del Programa.

Respecto al Realismo en las metas, no se registran, en los documentos revisados, el establecimiento de metas respecto de los objetivos que se plantean en el Programa. Tampoco existe una planificación como acción incorporada a la gestión curricular, considerando las condiciones de ingreso de las alumnas.

Considerando la Suficiencia de apoyos logrados, se observa que no existe evidencia que permita pronunciarse sobre apoyos logrados y su pertinencia y suficiencia. courses taking 396 hours; and in the "Specialized or Professional Training Area" (the area of "knowing to do"), there are 28 courses taking 2,128 hours.

We will not devote overmuch time to analyzing the distribution and consistency of courses according to the point in the programme when they are taught in consistency with the profile.

To sum up, as students progress through the programme, the courses they take may considered to shift gradually from the Basic Training ("knowing") Area to the Professional or Specialized Training ("knowing to do") Area. The first and second year of the programme focus on courses belonging to the General Training ("knowing to be") Area, in consistency with the degree profile.

\subsubsection{Fitness for the Context}

This dimension contains the information on responses to needs/shortfalls and the establishment of priorities in accordance with the context.

In the context we studied, the school's policy does not call for any special measures to ensure that students meet admissions standards, unless teachers see fit to take such measures on an individual basis. Programmes are planned in accordance with the training needs defined by the educational system. The degree programme's general outlines, including implementation conditions, must be submitted to the Mineduc authorities for accreditation, thus gaining authorization for the programme's operation. This process is sequential, so macro-level plans must be submitted at regular intervals.

\subsubsection{Fitness for the Situation at the Outset}

This aspect refers to the viability of the programme's execution.

With respect to realism in goals, the documents we examined do not record the establishment of any goals with respect to the objectives set in the programme. Nor is there any planning as an action incorporated into curricular management, considering the conditions of students at admission.

Considering the sufficiency of support actually achieved, we observed that there is no evidence for making any statements about the support actually achieved or its pertinence or sufficiency. 
En relación con los Cursos de capacitación para el Programa, la Escuela no posee cursos de capacitación para el Programa en sí mismo.

\subsection{Resultados del Programa en su desarrollo}

El segundo momento denominado "El Programa en su desarrollo", considera los criterios de conformidad, o falta de ella, entre la planificación y el desarrollo (desfases significativos, efectos no deseados o resultados parciales conformes o apartados de los previstos, representan elementos claves), grado en que un Programa innovador se incardinan efectivamente en el plan de centro o en un proyecto educativo (metodologías, actividades, valores incoherentes o alejados de la vida cotidiana del centro, pueden conducir a resultados distintos a los esperados) y la satisfacción personal.

Considerando la coherencia entre el perfil de la Carrera y los objetivos de las asignaturas del Plan de estudio por Área de Formación, los resultados reflejan que veinte asignaturas contribuyen al desarrollo de nueve competencias y se distribuyen secuencialmente entre el primer y cuarto semestre.

Se analizan, de modo análogo, el Área de Formación Especializada o Profesional, con los objetivos de las asignaturas, en las competencias "Del Saber Hacer". Se observa que tienen contribución veintiséis asignaturas distribuidas secuencialmente entre el tercer y octavo semestre. Se presenta una gran concentración de asignaturas de contribución a estas competencias en el quinto y sexto semestre. La contribución de las asignaturas al perfil se manifiesta en asignaturas de continuidad, sobre todo en los semestres quinto en adelante.

En relación con la Calidad técnica, se analizó la adecuación de los alumnos con el puntaje de ingreso de la Prueba de Selección Universitaria (PSU).

La Carrera no posee un ingreso a través de un puntaje, sólo existe una exigencia de que la PSU, esté rendida. Los puntajes de la PSU de las alumnas que ingresaron son bajos en comparación a cualquier Carrera, ya que se encuentran alrededor de los 300 puntos.

Al comparar los datos del período, se manifiesta una tendencia que indica que cada año tanto el puntaje de ingreso mínimo, como el máximo, son superiores a los del año anterior, por lo que podría indicar que cada año están ingresando alumnos con mejores requisitos de ingreso académico.
In connection with training courses for the programme, the school has no training courses for the programme itself.

\subsection{Results of the Programme in Its Implementation}

Point Two, “The Programme's Implementation", considers the criteria of conformity or lack thereof between planning and implementation (Significant gaps, undesired effects or partial results in accordance with or straying from the anticipated results are key elements), the degree to which an innovative programme fits effectively into the school's plan or educational project (Methodologies, activities and values that clash with or are unconnected with the school's daily life may lead to other than the expected results) and personal satisfaction.

Considering the consistency between the degree's profile and the objectives of the coursework set in the curriculum for each training area, the results show that twenty courses contribute to the development of nine competences, and these courses are distributed sequentially between the first semester and the fourth.

The Specialized or Professional Training Area is subjected to similar analysis in the light of the course objectives in the "knowing how to do" competences. Twenty-six courses, distributed sequentially between the third semester and the eighth, are observed to contribute. Courses contributing to these competences cluster heavily in the fifth and sixth semesters. The courses contribution to the profile is embodied in serial courses, especially from the fifth semester on.

In connection with technical quality, the fitness of the students in terms of their score on the Chilean university admissions test, the PSU, was analyzed.

There is no particular admissions test score that degree applicants must attain; students are only required to take the PSU. The students who entered the programme scored around 300 points on the PSU, which is a low score in comparison to any degree.

Comparison of the data for the period highlights a rising trend: Each year both the minimum and the maximum admissions scores of the programme's incoming students are higher than those of the year before. This might indicate that each year the inco- 
Otro de los indicadores de ingreso, son las notas de Enseñanza Media, las cuales indican la calidad académica de ingreso.

Como en el caso anterior, los datos indican que al comparar año a año las notas de Enseñanza Media de los alumnos que ingresaron a la Carrera, existe una tendencia a que tanto la nota máxima cómo la mínima son mayores que el período anterior, dato con el que se puede inferir que la calidad académica de los alumnos va en aumento. Respecto de los tipos de colegio de procedencia, los alumnos provienen mayoritariamente de la educación municipalizada y particular subencionada, muy pocos de colegios particulares, ya que su descripción psicosocial, indica que provienen de familias fundamentalmente de clase media, y media baja.

La ficha de alumno posee en su primera parte los antecedentes personales, como son el nombre apellidos, dirección y teléfonos; a continuación se indica los antecedentes de ingreso, como son: colegio de procedencia, notas de enseñanza media, puntaje PSU, y luego todos los antecedentes que el alumno va recopilando en su trayectoria académica.

No se realiza una entrevista para todos los alumnos, salvo para casos especiales, como por ejemplo cuando un alumno proviene de otra institución o país o presenta una situación de ingreso no habitual.

\subsection{Resultados del Programa en su desarrollo}

Los datos recogidos para los aspectos señalados, se obtuvieron de la aplicación de encuestas de opinión a alumnas y a profesores; además de entrevista a jefe de Carrera y profesores, según la pertinencia para cada aspecto.

\subsubsection{Ejecución del Programa}

En la "ejecución del Programa", se describieron las "adecuaciones de la metodologías para el desarrollo de los objetivos del Programa", el interés de las alumnas por "las actividades", la "secuencia de las actividades programadas", la "rigidez o flexibilidad en la aplicación del Programa" y "el profesor en sus actividad docente".

La "adecuación de las metodologías aplicadas para el desarrollo de los objetivos del Programa", manifiesta la mayor fortaleza en "la adecuación de la ming students are capable of meeting higher academic admissions requirements.

Another of the admissions indicators is incoming students' secondary school grades, which indicate academic quality at admission.

As in the case of admissions test scores, the data indicate that, in a year-to-year comparison, both the maximum and the minimum secondary school grades of the students enrolling in the degree programme are trending upward. From this data it may be inferred that the academic quality of students is rising. Incoming students come mainly from municipal-run and subsidized private schools. Very few come from wholly private schools, as their psycho-social description indicates that they come from fundamentally middle-class and lower middle-class families.

Each student record gives first the student's personal particulars, such as the student's full name, address and telephone numbers. Next it states the student's admissions particulars, such as former school, secondary school grades and admissions test score. After this the student's academic performance at the school is recorded.

Admissions interviews are not held for all students, but only in special cases, such as when a student transfers in from another university or country or when the admissions situation is somehow out of the ordinary.

\subsection{Results of the Programme in Its Implementation}

The information on the aspects stated below was gathered from opinion surveys administered to students and teachers and from interviews with the department director and teachers where pertinent to the aspect in question.

\subsubsection{Programme Execution}

In "Programme Execution" descriptions are given of the "adjustments of methodologies for the implementation of the programme's objectives", students' interest in "the activities" the "sequence of programmed activities", "rigidity or flexibility in the application of the programme" and "the teacher in his teaching activity".

"Adjustment of the methodologies applied for the implementation of the programme's objectives" shows its greatest strength in "adjustment of the 
metodología, según el carácter de la asignatura", según opinión de las alumnas de los niveles, segundo y cuarto, además de los profesores. Pero, las alumnas del nivel segundo y tercero indican que el aspecto mencionado representa la mayor debilidad. Agregan como debilidad los otros niveles a "la participación de las alumnas en la metodología", lo cual es corroborado por el Jefe de Carrera. Como prueba estadísticas se aplica el promedio, la media geométrica, la desviación estándar y el coeficiente de variación (véase Tabla 6). methodology to suit the nature of the course", according to the opinion of students of levels two and four and in the teachers' opinion. The students of level three, however, indicate that this aspect is the greatest weakness. The other levels add as a weakness "participation in the methodology by students", which is corroborated by the department director. The average, the geometric mean, the standard deviation and the coefficient of variation were applied as statistical tests (see Table 6).

Tabla 6. Síntesis de los resultados obtenidos

\section{INDICADORES}

\begin{tabular}{|c|c|c|c|c|c|}
\hline & & $\begin{array}{l}\text { 1. Tipo de } \\
\text { metodologías } \\
\text { aplicadas. }\end{array}$ & $\begin{array}{l}\text { 2. Adecuaciones de meto- } \\
\text { dologías, según caracterís- } \\
\text { ticas de las asignaturas. }\end{array}$ & $\begin{array}{l}\text { 3. Participación de los alum- } \\
\text { nos, según metodologías. }\end{array}$ & $\begin{array}{l}\text { 4. Material utilizado en el } \\
\text { desarrollo de las metodologías. }\end{array}$ \\
\hline \multirow{4}{*}{10} & $x$ & 81.25 & 79.76 & 73.66 & 77.00 \\
\hline & $M G$ & 77.86 & & & \\
\hline & DS & 3.22 & 1.73 & 1.77 & 2.15 \\
\hline & $\mathrm{CV}$ & 10.16 & 9.77 & 10.11 & 13.96 \\
\hline \multirow{4}{*}{20} & $x$ & 81.75 & 82.14 & 69.05 & 79.29 \\
\hline & $M G$ & & & 77.87 & \\
\hline & DS & 3.06 & 2.28 & 2.59 & 1.51 \\
\hline & $\mathrm{CV}$ & 10.41 & 13.90 & 15.60 & 9.50 \\
\hline \multirow{4}{*}{30} & $x$ & 79.97 & 83.16 & 87.11 & 80.26 \\
\hline & $M G$ & & & 82.58 & \\
\hline & DS & 4.04 & 2.01 & 1.87 & 1.99 \\
\hline & $\mathrm{CV}$ & 14.03 & 12.11 & 10.75 & 12.36 \\
\hline \multirow{8}{*}{$4^{\circ}$} & $x$ & 80.36 & 84.29 & 82.14 & 70.71 \\
\hline & $M G$ & 79.20 & & & \\
\hline & DS & 3.20 & 19.6 & 1.95 & 1.61 \\
\hline & $\mathrm{CV}$ & 11.07 & 11.60 & 11.89 & 11.42 \\
\hline & $x$ & 87.05 & 90.71 & 78.57 & 81.47 \\
\hline & $M G$ & & & 84.31 & \\
\hline & DS & 1.95 & 1.35 & 2.21 & 1.80 \\
\hline & CV & 6.99 & 7.46 & 14.08 & 11.04 \\
\hline
\end{tabular}

$X=$ promedio; $M G$ = media geométrica; $D S$ = desviación estándar; $C V$ = coeficiente de variación.

Fuente. Encuesta de opinión a alumnas y a profesores, elaboración propia. 
Table 6. Result Summary

INDICATORS

\begin{tabular}{|c|c|c|c|c|c|}
\hline & & $\begin{array}{l}\text { 1. Type of } \\
\text { methodologies } \\
\text { applied }\end{array}$ & $\begin{array}{l}\text { 2. Adjustments of } \\
\text { methodologies to suit } \\
\text { course characteristics }\end{array}$ & $\begin{array}{l}\text { 3. Student participation, } \\
\text { by methodology }\end{array}$ & $\begin{array}{l}\text { 4. Material used in the imple- } \\
\text { mentation of methodologies }\end{array}$ \\
\hline \multirow{4}{*}{10} & $x$ & 81.25 & 79.76 & 73.66 & 77.00 \\
\hline & $M G$ & 77.86 & & & \\
\hline & DS & 3.22 & 1.73 & 1.77 & 2.15 \\
\hline & $C V$ & 10.16 & 9.77 & 10.11 & 13.96 \\
\hline \multirow{4}{*}{20} & $x$ & 81.75 & 82.14 & 69.05 & 79.29 \\
\hline & $M G$ & & & 77.87 & \\
\hline & DS & 3.06 & 2.28 & 2.59 & 1.51 \\
\hline & $C V$ & 10.41 & 13.90 & 15.60 & 9.50 \\
\hline \multirow{4}{*}{30} & $x$ & 79.97 & 83.16 & 87.11 & 80.26 \\
\hline & $M G$ & & & 82.58 & \\
\hline & DS & $4 . \bigcirc 4$ & 2.01 & 1.87 & 1.99 \\
\hline & $C V$ & 14.03 & 12.11 & 10.75 & 12.36 \\
\hline \multirow{8}{*}{$4^{\circ}$} & $x$ & 80.36 & 84.29 & 82.14 & 70.71 \\
\hline & $M G$ & 79.20 & & & \\
\hline & DS & 3.20 & 19.6 & 1.95 & 1.61 \\
\hline & $C V$ & 11.07 & 11.60 & 11.89 & 11.42 \\
\hline & $x$ & 87.05 & 90.71 & 78.57 & 81.47 \\
\hline & $M G$ & & & 84.31 & \\
\hline & DS & 1.95 & 1.35 & 2.21 & 1.80 \\
\hline & CV & 6.99 & 7.46 & 14.08 & 11.04 \\
\hline
\end{tabular}

$\mathrm{X}=$ average; $\mathrm{GM}$ = geometric mean; $\mathrm{SD}$ = standard deviation; $\mathrm{CV}$ = coefficient of variation.

Source. Student and teacher opinion survey created by author.

El "interés de las alumnas en las actividades", manifiesta la mayor fortaleza en las opiniones vertidas en el "beneficios de las actividades al tipo de aprendizaje"; y la mayor debilidad en "la variedad de las actividades presentadas", lo cual es corroborado por el Jefe de Carrera.

La "secuencia de las actividades programadas", según opinión de las alumnas de todos los niveles, manifiesta la mayor fortaleza en el aspecto "coherencia de la asignatura con las anteriores"; sin embargo, en opinión de los profesores estaría en la
"Student interest in the activities" displays its greatest strength in the opinions given on the "benefits of the activities for the type of learning", and its greatest weakness, in "variety of the activities presented", which is corroborated by the department director.

The "sequence of programmed activities", in the opinion of the students of all levels, displays its greatest strength in "consistency of the course with previous courses"; however, in the teachers' opinion, its foremost strength is the "contribution of the course 
“contribución de la asignatura con otras del Programa". La mayor debilidad manifestada por las alumnas y profesores está en "escenarios para el desarrollo de las diferentes asignaturas", lo cual es corroborado por el Jefe de Carrera.

La "rigidez / flexibilización del Programa", según opinión de los profesores, manifiesta la mayor fortaleza en "la estructura de las planificaciones", pero su mayor debilidad en la "imposibilidad de adecuaciones de aspectos, períodos y escenarios de desarrollo de las planificaciones".

El "profesor en su actividad docente", según opinión de las alumnas de todos los niveles, manifiesta su mayor fortaleza en la "evaluación de los aprendizajes", y según opinión de los profesores, está en la "presentación de nuevos contenidos". La mayor debilidad, según opinión tanto de alumnas como de profesores, está en "revisión de los aprendizajes logrados por las alumnas."

\subsubsection{Marco de desarrollo del Programa}

En el "marco de desarrollo del Programa", se describió el "clima", considerando "clima entre los alumnos y entre alumnos con Jefe de Carrera", "clima entre el "profesor y el alumnado", "clima entre el alumno y el personal de apoyo académicos y de servicios", y "clima entre el personal (referido a profesores)"

El "clima entre los alumnos y entre alumnos con Jefe de Carrera", manifiesta la mayor fortaleza para las alumnas de primer año en la "comunicación formal entre pares"; pero que en los otros niveles representa una debilidad. Respecto del "clima entre alumnas y Jefe de Carrera", todos los niveles manifiestan un nivel inferior al estándar establecido como aceptable en la encuesta de opinión, y aún más bajo está el aspecto referido a "liderazgo del Jefe de Carrera", también por manifestación de las alumnas de todos los niveles.

El "clima entre profesor y alumnado" manifiesta la mayor fortaleza, según las alumnas de todos los niveles y los profesores en el indicador "expectativas del alumno respecto de su rendimiento", seguido de "comunicación formal entre profesor y alumno", en los niveles primero, tercero y cuarto de las alumnas. Otro indicador de fortaleza para las alumnas de primero, tercero y cuarto, corresponde a "percep- with other courses in the programme". The greatest weakness claimed by students and teachers is "stages for the implementation of the different courses", which is corroborated by the department director.

"Rigidity/flexibility of the programme", in the opinion of teachers, displays its greatest strength in "planning structure" but its greatest weakness is in the "impossibility of adjusting aspects, periods and stages for planning implementation".

The "teacher in his teaching activity" has its greatest strength in "evaluation of what is learned" in the opinion of students of all levels, while teachers feel that the "presentation of new contents" is the greatest strength. The greatest weakness, in the opinion of students and teachers alike, is "review of what has been learned by the students".

\subsubsection{Framework of Programme Implementation}

In the "framework of programme implementation", a description of the "climate" is given. This description includes "climate among students and between students and the department director", "climate between teachers and the student body", "climate between students and the supporting academic and service staff" and "climate among staff (referring to teachers)".

The "climate among students and between students and the department director" displays its greatest strength for first-year students in "formal communication among peers", but for the other students "formal communication among peers" is a weakness. With respect to the "climate between students and the department director", all student groups report a level below the standard established as acceptable in the opinion survey, and the aspect referring to "department director leadership" scores even lower, also according to statements from the students of all groups.

The greatest strength of "climate between teacher and the student body", according to students of all groups and teachers, is the indicator measuring "student expectations with respect to their performance", followed by "formal communication between teacher and student" for the first-, third- and 
ción del alumno respecto de las expectativas del éxito académico que manifiestan sus profesores". La mayor debilidad está en "la comunicación real entre profesor y alumno", salvo para el nivel tercer año.

Cabe hacer presente y llama la atención que el nivel segundo año, en todos los aspectos del clima analizado que tienen relación con el profesor, manifiestan opiniones que están bajo el estándar considerado aceptable para la interpretación de los datos de la encuesta; por otro lado, que según opinión de los profesores, todos los ámbitos que tienen injerencias manifiestan opiniones bajo el estándar aceptable.

El "clima entre el alumno y el personal de apoyo académicos y de servicios", manifiesta su mayor fortaleza en el indicador "comunicación del alumno con personal de servicio de casino, manutención y aseo de recintos", salvo para el nivel cuarto año. La mayor debilidad se manifiesta para las alumnas de todos los niveles en el indicador "comunicación del alumno con personal de apoyo: secretarias, biblioteca central de apuntes".

El "clima entre el personal (referido a profesores)" manifiesta su mayor fortaleza, según opinión del profesorado, en "vías de comunicación del profesor con jefe de Carrera" y su mayor debilidad en "comunicación formal entre pares" (véase Gráfico 1)

\section{Gráfico 1. Clima entre el personal}

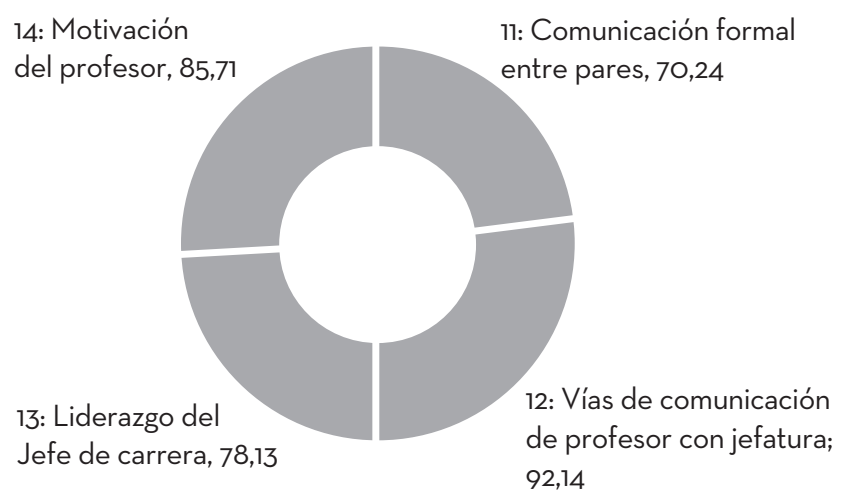

MEDIA GEOMETRICA: 81,14

Fuente: Encuesta de opinión dirigida a profesores.

\subsection{Resultados del Programa en sus resultados}

El Programa de la Carrera de FEP, en su análisis del "Programa en sus resultados", consideró los ámbi- fourth-year students. Another indicator of strength for first-, third- and fourth-year students is "student perception with respect to the expectations of academic success manifested by their teachers". The greatest weakness lies in "real communication between teacher and student", save for the third-year students.

It is worthwhile to draw attention to the fact that, in all teacher-related aspects of the climate, the thirdyear class reports opinions that are below the standard considered acceptable for the interpretation of the survey data.

The "climate between students and the supporting academic and service staff" displays its greatest strength in the indicator measuring "communication by students with dining hall, maintenance and cleaning service staff" for all students save those in the fourth year. Students of all groups report the greatest weakness to be the indicator measuring "communication by students with support staff: secretaries, central class note library".

The "climate among staff (referring to teachers)" displays its greatest strength, in the teachers' opinion, in "channels for teacher communication with the department director", and its greatest weakness, in "formal communication among peers" (see Chart 1).

Chart 1. Climate Among Staff

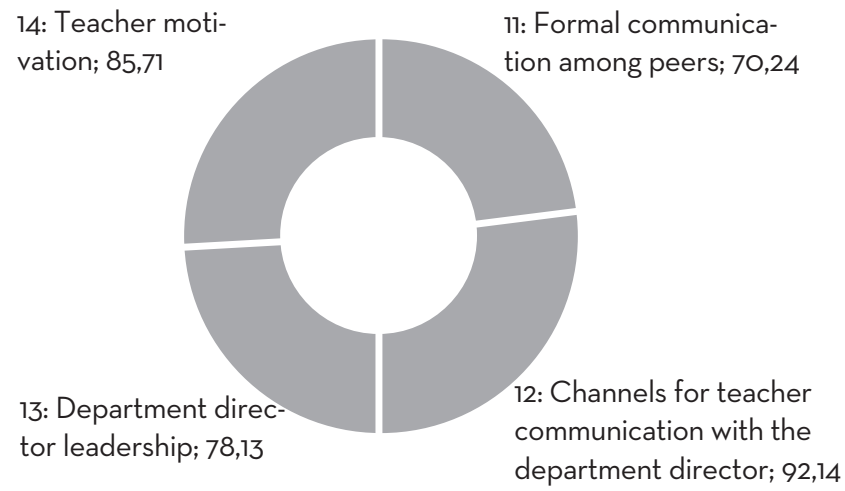

GEOMETRIC MEAN: 81.14

Source: Teacher opinion survey

\subsection{Results of the Programme in Its Results}

In its analysis of the "programme in its results", the ECET degree programme considered the spheres of 
tos de "medidas y logros", "valoración" y “continuidad", los cuales representan los referentes para la interpretación de la información.

\subsubsection{Medidas y logros}

Las medidas y logros, considerando la constatación y contraste de los procesos referidos a instrumentos de evaluación, el aseguramiento de su calidad técnica, planificación y criterios de calificación y niveles de logro y tomando como referentes los datos registrados de éstos procesos, indican que la planificación de los procesos de medición está definido por la Jefatura de Carrera, así como la cantidad de calificaciones por asignatura. Pero no existe supervisión y puesta en común sobre criterios de elaboración de instrumentos y el asegurar su calidad técnica, como tampoco orientaciones de administración.

Los registros de resultados están definidos y calendarizados y la única exigencia es que al final de cada período semestral, los instrumentos aplicados durante el semestre deben dejarse archivados en la capeta de asignatura correspondiente, con el examen final, pauta de corrección y calificaciones registradas con firma de toma de conocimiento por parte del alumnado.

Los criterios de calificación no están definidos reglamentariamente, existe instrucción verbal de establecer un criterio de exigencia del sesenta por ciento, cuya aplicación se cautela y supervisa en su aplicación del examen.

\subsubsection{Valoración}

No existen criterios registrados que den cuenta de la valoración y niveles conseguidos con el Programa.

El aspecto que se puede registrar es que el ingreso anual en períodos consecutivos, ha manifestado una tendencia a aumentar.

\subsubsection{Continuidad}

No hay un plan de seguimiento por promoción de la Carrera, de manera general, como tampoco en la continuidad de las asignaturas pro cada profesor. No obstante, al conocer resultados parciales del presente estudio, se inició la planificación de un pro- "measurements and achievements", "assessment" and "continuity", which represented the benchmarks for interpreting the information.

\subsubsection{Measurements and Achievements}

Measurements and achievements are looked at in terms of verification and contrast of the processes referring to evaluation instruments, assurance of the technical quality of evaluation instruments, planning and grading criteria and achievement levels. The benchmarks for measurements and achievements are given by the recorded data on these processes. Measurement processes are defined by the department director, as is the number of grades per course, but the criteria for creating instruments and assuring the technical quality of those instruments are neither supervised nor standardized, nor does any administrative steering exist.

The records of results are defined and set to a calendar, and the sole requirement is that, at the end of each semester, the instruments applied during the semester must be filed in the correct course folder with the final exam, correction key and recorded grades, bearing the student's signature in acknowledgement.

Grading criteria are not defined by regulation. There are oral instructions to establish a performance requirement of sixty percent, whose application to exams is guarded and supervised.

\subsubsection{Assessment}

There are no recorded criteria reporting assessments and levels achieved with the programme.

The aspect that can be recorded is that yearly admissions in consecutive periods have displayed an upward tendency.

\subsubsection{Continuity}

There is no plan for tracking each class's performance either generally or in the continuity of the courses taught by each teacher. Nevertheless, when this study brought its partial results to light, planning was begun for an improvement 
yecto de mejoramiento, considerando aspectos de proceso fundamentales.

\section{Conclusiones}

Presentamos las principales conclusiones derivadas de los resultados obtenidos $y$, a su vez, referentes a las preguntas de la investigación y a los objetivos específicos.

\subsection{Relacionadas con las preguntas de investigación}

En relación con la constatación en los documentos oficiales de la institución para la Carrera de PEP con mención en $\mathrm{NB}$ 1, de la presencia de las orientaciones, políticas y requerimientos del modelo educativo institucional como requerimientos mínimos para el desarrollo de la formación de estos profesionales y de acuerdo a los datos recopilados mediante análisis documental, se concluye:

- En los documentos oficiales de la Carrera de PEP se comprueba la presencia de las orientaciones, políticas y requerimientos del modelo educacional de la institución UBO, centro del estudio.

En relación al grado de relación existe entre las propuestas indicadas en los documentos oficiales de la Carrera de PEP con mención en $\mathrm{NB}$, referidas a aspectos curriculares de formación y valórica, con su implementación en actividades de aula y terreno, se concluye:

- Se constata la inexistencia de relación entre las propuestas indicadas en los documentos oficiales de la Carrera con la gestión curricular, en sus aspectos de liderazgo y ejecución de acciones, como también en los elementos de coherencia, interacción y secuencia de éstas para asegurar la concreción de lo planteado.

En relación al grado de asunción del logro de los objetivos curriculares y de los valores planteados por la institución manifiestan los actores del proceso de formación de la Carrera de PEP, se concluye.

- No existe -tanto para las alumnas como para los profesores- un grado de asunción del logro de objetivos curriculares y de los valores plantea- project considering fundamental aspects of the process.

\section{Conclusions}

The main conclusions drawn from the results, referring in their turn to the research questions and the specific objectives, are presented below.

\subsection{Conclusions Related with the Research Questions}

The official university documents for the ECET degree (major in first-year primary school teaching) were examined to verify that they contain guidelines, policies and requirements established under the university's educational model as minimum requirements for the implementation of the training of early childhood educators. It was concluded from the data gathered via documentary analysis that:

- The official ECET degree documents do contain the guidelines, policies and requirements of the educational model espoused by the school, Bernardo O'Higgins University.

An examination was conducted to determine the degree of relationship between the proposals indicated in the official documents of the ECET degree (major in first-year primary school teaching) referring to curricular and value-related aspects of training and the implementation of those proposals in classroom and field activities, and it was concluded that:

- No relationship is found between the proposals indicated in the official degree documents and curricular management in terms of the aspects of leadership and action execution or in the elements of consistency, interaction and sequencing to ensure the attainment of the proposals.

In connection with the amount of internalization of the achievement of the curricular objectives and values supported by the institution, as reported by the active participants in the ECET degree training process, it was concluded that:

- For students and teachers alike, there is no internalization of the achievement of curricular ob- 
dos por la institución. No obstante, la visión del Jefe de Carrera, se orienta en sentido contrario a las opiniones de los protagonistas centrarles del proceso.

En relación a las explicaciones que dan las alumnas y profesores acerca de la vivencia de los valores propuestos, se llega a la siguiente conclusión:

- Se considera rigidez de las programaciones y planificaciones, la falta de comunicación real entre los actores, la falta de metodologías variadas, la poca comunicación con los profesores y Jefe de Carrera, la falta de liderazgo del jefe de Carrera.

\subsection{Relacionadas con los objetivos específicos}

En relación con el hecho de detectar fortalezas y debilidades de la estructura del programa de formación de educadores de párvulos con mención en $\mathrm{NB} 1$, con respecto al proyecto educativo presentado por la universidad, se concluye:

- Las fortalezas se evidencian en la coherencia de los aspectos establecidos en la Misión de la Universidad con los objetivos de la Carrera, la coherencia entre el perfil (competencias) con las asignaturas del plan de estudio, y la coherencia entre las competencias con los objetivos de cada una de las asignaturas, considerando los ámbitos de formación del "saber, del "ser" y del "hacer".

En relación con el contraste entre el nivel de desarrollo de las propuestas indicadas en los documentos oficiales de la Carrera de PEP y la ejecución de los aspectos curriculares de formación y valórica", se llega a la siguiente conclusión:

- Las propuestas teóricas consideradas para el desarrollo del Programa, no concuerdan con las acciones determinadas para la ejecución y el marco de desarrollo del Programa, evidenciándose una falta de gestión curricular, de management, destacando falta de conducción del proceso, interacción entre los integrantes, reflexión y análisis crítico de lo realizado.

Al pretender determinar los niveles de logro de las propuestas indicadas en los documentos oficiales de la Carrera de PEP, desde la perspectiva de los docentes y estudiantes", se concluye: jectives and values supported by the institution. Nevertheless, the views of the department director are the opposite of opinions of the central protagonists of the process.

In connection with the explanations given by students and teachers about how the proposed values are experienced, the following conclusion was reached:

- Programming and planning regarded as rigid; lack of real communication among the active participants; lack of varied methodologies; little communication with teachers and the department director; lack of leadership by the department director.

\subsection{Conclusions Related with Specific Objectives}

In connection with the detection of strengths and weaknesses in the structure of the programme for training early childhood educators majoring in firstyear primary school teaching, with respect to the educational project presented by the university, it was concluded that:

- The programme's strengths lie in the consistency of the aspects established in the university's mission statement with the degree's objectives, the consistency between the profile (competences) and the courses called for in the curriculum, and the consistency between the competences and the objectives of each of the courses, considering the education spheres of "knowing", "being" and "doing".

In connection with the contrast between the level of development of the proposals stated in the official ECET degree documents and the actual execution of the curricular aspects of training and values, the following conclusion was reached:

- The theoretical proposals considered for the implementation of the programme do not match the actions mapped out for the programme's execution and implementation framework. Curricular management is found to be lacking. The main points lacking are process steering, interaction among the participants in the process, reflection and critical analysis of what has been done.

After endeavouring to determine the levels of achievement of the proposals made in the official 
- Desde la perspectiva de los estudiantes y profesores, no hay claridad en los niveles de logro, pues no existen referentes anteriores concretos y los propios del desarrollo de la Carrera no están registrados y sistematizados, con criterios claros y comunes.

\subsection{Relacionadas con el objetivo general}

Considerando la coherencia que presenta el programa de la Carrera de FEP con mención en NB1, en su estructura, desarrollo y logros con el proyecto presentado por la Universidad Bernardo O 'Higgins, en el período 2009-2012, se concluye:

- La descripción de la estructura del Programa de la Carrera de FEP tiene una coherencia con los documentos oficiales de la Universidad, representados por la Misión de la Universidad y con los direccionales de la Carrera, como perfil de egreso y plan de estudio.

- No obstante lo anterior, no se evidencia una coherencia entre esta estructura y la ejecución del Programa, existiendo aspectos de inconsistencia o no desarrollo, supervisión y control de los procesos.

- Como consecuencia, existe una falta de referentes concretos para evidenciar los niveles de logros, en el desarrollo del Programa y en los resultados obtenidos por la ejecución de éste y también, en el análisis de los aspectos que requieren ajustes, modificaciones o elementos de continuidad.
ECET degree documents from the perspective of teachers and students, it was concluded that:

- From the perspective of students and teachers, there is no clarity in achievement levels, because there are no specific prior benchmarks, and the benchmarks of the degree's implementation are not recorded and systematized under clear, common criteria.

\subsection{Conclusions Related with the General Objective}

The ECET degree programme (major in first-year primary school teaching) was examined, in terms of structure, development and achievements, for consistency with the project presented by Bernardo O'Higgins University for 2009-2012. It was concluded that:

- The description of the structure of the ECET degree programme is consistent with the official university documents represented by the university's mission statement and the degree steering documents, such as the output profile and the curriculum.

- Nevertheless, there is no consistency found between this structure and the programme's execution. There are aspects of inconsistency or lack of implementation, supervision and process control.

- As a consequence, there is a lack of specific benchmarks for finding achievement levels in the implementation of the programme, in the results of the programme's execution and in the analysis of aspects that require adjustment, modification or elements of continuity.

\section{Bibliografía / Bibliography}

Aguado, T., Gil, I. \& Mata, P. (2008). El enfoque intercultural en la formación del profesorado. Dilemas y propuestas. Revista Complutense de Educación, vol. 19, No. 2.

Brunner, J.J. (1995). Desarrollo regional y universidades. OECD.

Coll, C. (2008). Psicología y currículum. Buenos Aires: Paidós.

Eisner, E.W. (1994). Cognition and Curriculum Reconsidered. 2nd ed. New York: Teachers College Press.

Fernández Sierra, J. \& Santos, M.A. (1992). Evaluación cualitativa de programas de educación para la salud. Málaga: Archidona.

García Llamas, J.L. (2003). Métodos de investigación en educación. Investigación cualitativa y evaluativa. Madrid: UNED. 
Garrido, M. (1989). La formación del maestro en la sociedad actual: Consecuencias inmediatas y nuevas perspectivas formativas. Revista Electrónica Interuniversitaria de Formación del Profesorado, No. 2 (1).

Guba, E. \& Lincoln, Y. (1989). Fourth Generation Evaluation. California: Newsbury Park.

Himmel, E., Olivares M.A. \& Zabalza, J. (1999). Hacia una evaluación educativa. Aprender para evaluar y evaluar para aprender. Chile: Pontificia Universidad Católica de Chile.

Horrillo, M.A. (2005). Evaluación de programas educativos. UNED. Madrid.

Jiménez, M.A. \& Navaridas, F. (2012). Cómo son y qué hacen los “maestros excelentes": la opinión de los estudiantes. Revista Complutense de Educación, vol. 23, No. 2.

Maciel de Oliveira, C. (2003). La investigación-acción como estrategia de aprendizaje en la Formación Inicial del Profesorado. Revista lberoamericana de Educación, No. 33.

Mineduc (1999). Decreto de Evaluación no 112. Downloaded from www.mineduc.cl.

Murillo, F.J. (2006). Modelos innovadores en la formación inicial docente. Estudio de casos (...) en América Latina y Europa. UNESCO: Regional Bureau for Education in Latin America and the Caribbean.

Parlett, M. \& Hamilton, D. (1972). Evaluation and Illumination, reprinted in Tawney, D. (1976). Curriculum Evaluation Today. Trends and Implications. London: McMillan.

Pérez Juste, R., García Llamas, J.L. \& Martínez Mediano, C. (1995). Evaluación de programas y centros educativos. Madrid: UNED.

Pérez Juste, R. (2000). La evaluación de programas educativos: conceptos básicos, planteamientos generales y problemáticas. Revista de Investigación Educativa, vol. 18, No. 2.

Pérez Serrano, G. (2001). Modelos de investigación cualitativa. Madrid: Narcea.

Román Pérez, M. (2004). Sociedad del conocimiento y refundación de la escuela desde el aula. Madrid: Facultad de Educación, Universidad Complutense.

Rossi, P.H. \& Freeman, H.E. (1971). Evaluación: Un enfoque sistemático para programas sociales. Mexico: Trillas. Scriven, M. (1997). La metodología en evaluación. New York: Rand McNally.

Stake, R.E. (1975). Program Evaluation, Particularly Responsive Evaluation. Western Michigan University Evaluation Center.

Stufflebeam, D. \& Shinkfield, A. (1987). Evaluación sistemática. Guía teórica y práctica. Barcelona.

Tyler, R.W. (1949). Principios básicos de curriculum. Universidad de Chicago.

Universidad Bernardo O'Higgins (2008). Programa Carrera Educación Parvularia Mención NB1. Santiago de Chile: Facultad de Educación.

\section{Notas / Notes}

${ }^{1}$ Este trabajo se ubica en el Programa de Doctorado del Departamento de Teoría de la Educación y Pedagogía Social de la UNED.

2 This paper was written for the doctorate programme at the Spanish National Distance Education University's Department of Education Theory and Social Pedagogy.

3 Término utilizado en diversos países latinoamericanos equivalente a la Educación Infantil en España.

4 Nivel Básico 1
5 Como sugiere la RAE, en este trabajo se hace un uso genérico para designar a los dos sexos.

${ }^{6}$ Citado por Maciel de Oliveira, C. (2003)

7 Citado por Román, M. (2004)

8 Quoted by Maciel de Oliveira, C. (2003).

9 Quoted by Román, M. (2004). 


\section{CÓMO CITAR ESTE ARTÍCULO / HOW TO CITE THE ARTICLE}

Arias Meriño, M. E. (2014). Formación de educadores de párvulos como servicio a la sociedad. Pedagogía Social. Revista Interuniversitaria, 24 225-252. doi:10.7179/PSRI_2014.24.10

Arias Meriño, M. E. (2014). Early childhood educator training as a service to society. Pedagogía Social. Revista Interuniversitaria, 24 225-252. doi:10.7179/PSRI_2014.24.10

\section{DIRECCIÓN DEL AUTORA / AUTHOR' ADDRESSES}

Universidad Mayor. Calle Manuela Montt 367. Providencia. Santiago de Chile.

Dirección de correo / E-mail: mariaeliana_arias@yahoo.es

Fecha de recepción del artículo: 20.II.2014

Fecha de revisión del artículo: 23. 11.2014

Fecha de aceptación final: 10. IV.2014

\section{PERFIL ACADÉMICO / ACADEMIC PROFILE}

María Eliana Arias Meriño. Magister en Educación con mención en Administración Educacional. Licenciada en Educación por la Pontificia Universidad Católica de Chile. Ha sido profesora en la Universidad Mayor de Chile. Ha ejercido, entre otros, los cargos de Asesora Educacional Carabineros de Chile, Secretaria General Académico del Instituto Profesional Providencia de Santiago, Directora de Educación Corporación Municipal de Rancagua. Las líneas de investigación principales son: 1. Metodología de la investigación. 2. Evaluación. 3. Diseño e implementación de proyectos educativos en el ámbito de la Educación Superior. 